\title{
АРИДИЗАЦИЯ ЗАСУШЛИВЫХ ЗЕМЕЛЬ ЕВРОПЕЙСКОЙ ЧАСТИ РОССИИ И СВЯЗЬ С ЗАСУХАМИ
}

\author{
(C) 2020 г. А. Н. Золотокрылин ${ }^{a}$, Е. А. Черенкова ${ }^{a, *}$, Т. Б. Титкова ${ }^{a}$ \\ ${ }^{a}$ Институт географии РАН, Москва, Россия \\ *e-mail: cherenkova@igras.ru \\ Поступила в редакцию 01.04.2019 г. \\ После доработки 27.09.2019 г. \\ Принята к публикации 28.11.2019 г.
}

\begin{abstract}
Исследованы тренды увлажнения в семи областях юга Европейской части России (ЕЧР), оценен тренд деградации земель по данным спутникового альбедо в начале текущего столетия. Установлено, что взаимная компенсация внутривековых колебаний индекса аридности свидетельствует об устойчивости аридных зон на засушливых землях. Незначимость линейных трендов индекса аридности за период 1901-2012 гг. не подтверждает гипотезу о систематическом усилении аридизации в условиях продолжающегося глобального потепления. Выполнен анализ периодов группировок засушливых и влажных лет различной длительности. Выявлено, что частота весенних засух имеет тенденцию к снижению, а их интенсивность была максимальной в десятилетие 1981-1990 гг. Частота и интенсивность летних засух повышалась в периоды группировок лет усиления аридизации. На усиление аридизации в большей степени влиял рост частоты и интенсивности летних засух, чем весенних. В условиях отсутствия прогресса аридизации засушливых земель ЕЧР в течение более, чем 100 лет, выявленная нарастающая деградация земель становится доминирующим фактором опустынивания.
\end{abstract}

Ключевые слова: тренды, индекс аридности, стандартизированный индекс осадков, засуха, засушливые земли, Европейская часть России

DOI: $10.31857 /$ S258755662002017X

\section{ВВЕДЕНИЕ}

Анализ временных рядов коэффициента увлажнения (отношение годового количества осадков к годовой испаряемости) на засушливых землях ЕЧР в XX в., границы которых были впервые определены в работе [2], обнаружил внутривековые разнонаправленные тренды увлажнения, связанные с многолетними колебаниями годовых осадков продолжительностью несколько десятилетий $[3,4,12]$. В масштабе более века это означает возможную компенсацию колебаний увлажнения, поддерживающую устойчивость зон увлажнения [12]. Сравнение модельных оценок современного и ожидаемого к концу первой трети XXI в. положения границ зон увлажнения в условиях антропогенного потепления также не показало их статистически достоверного смещения [13].

Такое объяснение устойчивости зон увлажнения не бесспорно, поскольку испаряемость в формуле коэффициента увлажнения вычислялась как функция температуры по методу Торнтвейта [19]. Уменьшить неопределенность в трактовке можно с помощью аналога коэффициента увлажнения - индекса аридности (Aridity Index,
AI), рекомендованного Конвенцией ООН по борьбе с опустыниванием для классификации степени аридности территории [21]. Индекс аридности определяется как отношение ежегодного уровня осадков (мм) к суммарной за год потенциальной эвапотранспирации (мм), вычисляемой более физически обоснованным методом Пенмана $[18,19]$, чем при расчете по методу Торнтвейта [20].

Процесс аридизации климата развивается преимущественно в теплое время года в условиях сокращения осадков по отношению к среднему уровню и сопровождается повышением температуры воздуха, испаряемости и дефицита влажности воздуха. Поскольку изменения этих метеорологических элементов в совокупности характеризуют атмосферную засуху, то ее следует рассматривать в качестве комплексного фактора аридизации. В этом случае совместный анализ изменений индекса аридности и характеристик засух (продолжительности, частоты, интенсивности) важен для изучения процесса аридизации.

Исследование направлено на понимание причин устойчивости границ аридных зон на ЕЧР за 
период 1901-2012 гг. в условиях меняющегося климата.

Цель исследования состоит в том, чтобы сравнить размещение аридных зон в заданные климатические эпизоды, оценить тренды индекса аридности, частоты и интенсивности засух. Выявить колебания аридизации на основании выделенных группировок несколько лет подряд ниже (выше) среднего индекса аридности, характеризующих соответственно усиление (ослабление) аридизации, а также оценить роль группировок засух в усилении аридизации.

Важную часть исследования составляет анализ динамики границ субгумидной, сухой субгумидной и семиаридной зон во время группировок лет усиления (ослабления) аридизации. Для общей характеристики опустынивания предполагается сравнить на уровне субъектов РФ тренды климатической составляющей опустынивания (индекс аридности и характеристики засух), а также деградации земель по спутниковым данным за последние два десятилетия.

\section{ТЕРРИТОРИЯ, МАТЕРИАЛЫ, ПУТЬ РЕШЕНИЯ ЗАДАЧИ}

Территория исследования представлена субгумидными, сухими субгумидными, семиаридными зонами ЕЧР, на которой расположены следующие субъекты РФ: Оренбургская, Саратовская, Волгоградская, Астраханская, Ростовская области, Республика Калмыкия и Ставропольский край.

Изолиния индекса аридности 0.5 , отделяющая сухую субгумидную зону от субгумидной, проходит через четыре области: Оренбургскую, Саратовскую, Ростовскую и Ставропольский край (рис. 1). В среднем в первых трех областях субгумидные условия наблюдались в $65 \%$ лет. В остальные годы условия приближались к сухим субгумидным, включая 5\% лет, когда наблюдались семиаридные условия. Волгоградская область и Ставропольский край - это сухие субгумидные территориии, хотя примерно в $35 \%$ лет в этих областях возможно распространение субгумидных условий. И, наконец, в Астраханской области семиаридные условия характерны в $87 \%$ лет, а в $13 \%$ лет возможны сухие субгумидные. В Республике Калмыкия сухие субгумидные условия наблюдались в 47\% лет, а семиаридные - в 53\%.

Степень аридизации в субъектах РФ оценивалась по индексу аридности, в котором потенциальная эвапотранспирация вычислялась по методу Пенмана $[18,19]$. В расчете используются данные о радиационном балансе поверхности, температуре, относительной влажности воздуха и скорости ветра. В отличие от достаточно густой сети метеостанций количество актинометрических станций ограничено, что вынуждает для оценки составля- ющих радиационного баланса использовать также расчетные методы. Ранее авторами было выполнено сравнение различных методов расчета испаряемости на юге Русской равнины, в результате которого метод Пенмана был отнесен к наиболее надежным методам [11].

Индекс аридности вычислялся по данным глобальных архивов среднемесячных осадков и потенциальной эвапотранспирации по Пенману с пространственным разрешением $0.5 \times 0.5^{\circ}(\mathrm{Cli}-$ matic Research Unit, CRU TS3.21, [17]) за период 1901-2012 гг. Затем индекс усреднялся в границах субъектов РФ. При этом потенциальная эвапотранспирация рассчитана по формуле, которая характеризует испарение с гипотетического хорошо развитого зеленого травяного покрова высотой 0.12 м и с полностью увлажненной почвы. Данный метод расчета испаряемости рекомендован Продовольственной и сельскохозяйственной организацией ОOH (Food and Agriculture Organization, FAO) [16].

Распространение весенних и летних засух на территории исследовано с помощью трехмесячного стандартизованного индекса осадков (Standardized Precipitation Index, SPI) в мае (март-май) и августе (июнь-август). Методика расчета индекса и особенности повторяемости атмосферных засух согласно их классификации по SPI на Европейской территории России подробно были описаны нами в работе [14]. Ввиду осреднения значений SPI в пределах субъектов, которое в целом сглаживает региональное проявление засухи, решено было рассматривать не значения индекса ниже -1 (идентифицирующие засуху), а все отрицательные значения индекса, включающие засушливые условия и засухи различной интенсивности.

Альбедо поверхности (спутниковый продукт MODIS: https://lpdaac.usgs.gov/dataset_discovery/ modis/modis_products_table) использовано в качестве комплексного индикатора деградации почв, зависящего от состояния ее поверхности, включая ее влажность, тип растительности, степень эродированности, склонность к осолонцеванию почв и т.д. Положительные тренды спектрального альбедо характеризуют деградацию земель на уровне субъектов РФ в мае и августе за период 2000-2018 гг.

Сеточные данные иандекса аридности (AI), засух (SPI) и альбедо (AL) осреднялись в пределах обозначенных субъектов РФ. Затем формировались многолетние ряды и вычислялись их статистические характеристики (среднее, стандартное отклонение, коэффициенты линейных трендов с оценкой их статистической достоверности) за периоды 1901-2012; 1901-1930; 1931-1960; 19611990; 1991-2012 гг. Отдельно анализировались ряды AI со значениями менее среднего значения 


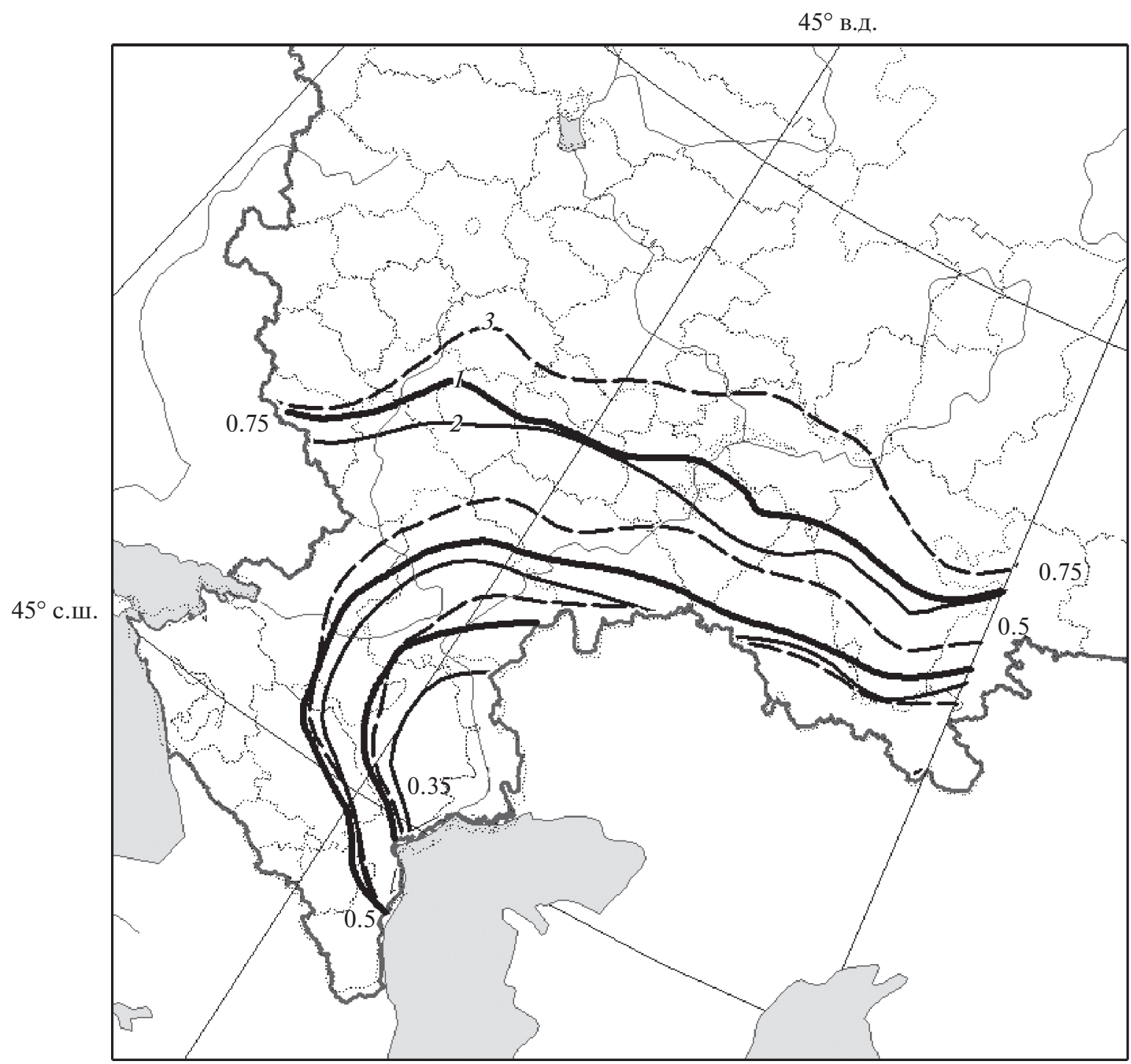

Рис. 1. Северные границы аридных зон (изолинии со значениями 0.35 (семиаридная зона), 0.50 (сухая субгумидная зона) и 0.75 (субгумидная зона)) в периоды усиления аридизации (1930-1939 гг.) и ее ослабления (1987-1996 гг.). Изолинии: 1 - (1901-2012 гг.), 2-(1987-1996 гг.), 3 - (1930-1939 гг.).

(усиление аридизации) и выше среднего значения (ослабление аридизации) и соответственно строились гистограммы частоты (повторяемости) группировок указанных значений AI.

Распространение весенних и летних засух на уровне субъектов исследовано по данным трехмесячного SPI соответственно для мая (март-май) и августа (июнь-август) за периоды 1901-2012; 1901-1930; 1931-1960; 1961-1990; 1991-2012 гг. Так же, как и для рядов индекса аридности, вычислялись статистические характеристики рядов частоты и интенсивности весенних и летних засух.

\section{ОСНОВНЫЕ РЕЗУЛЬТАТЫ И ИХ ОБСУЖДЕНИЕ}

Основной результат исследования объясняет развитие аридизации в заданных субъектах РФ за последние более чем 100 лет. Установлена ярко выраженная междугодовая изменчивость индекса аридности, маскирующая разнонаправленные внутривековые изменения индекса. Полученные оценки вклада линейных трендов в изменчивость индекса аридности в сравниваемых субъектах РФ за весь период наблюдений свидетельствуют, что их доля составляет менее первых процентов. 
Al

0.5

0.5
0.4

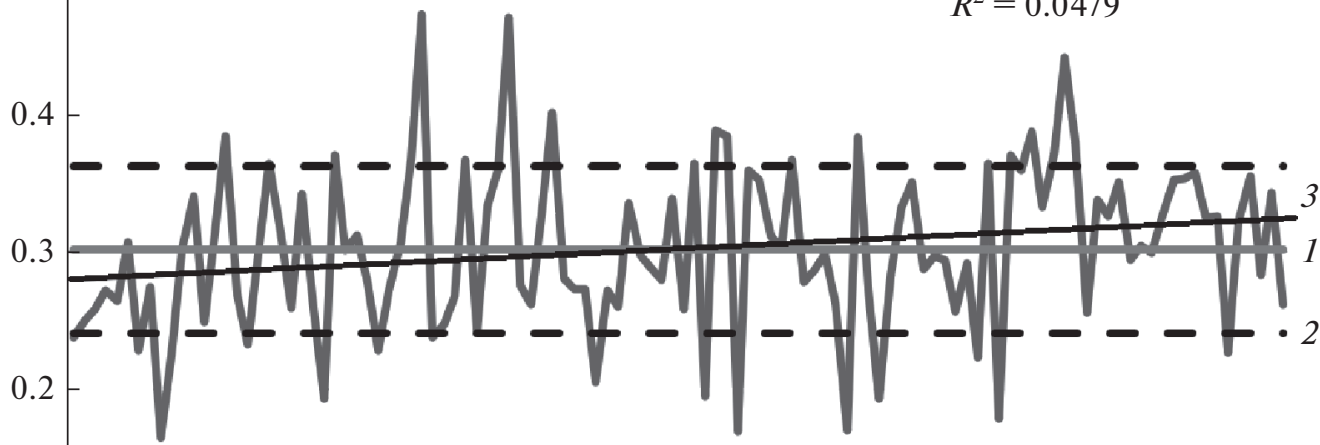

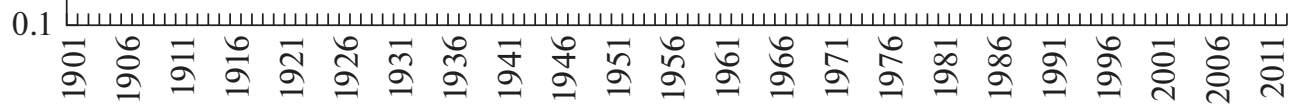
Годы

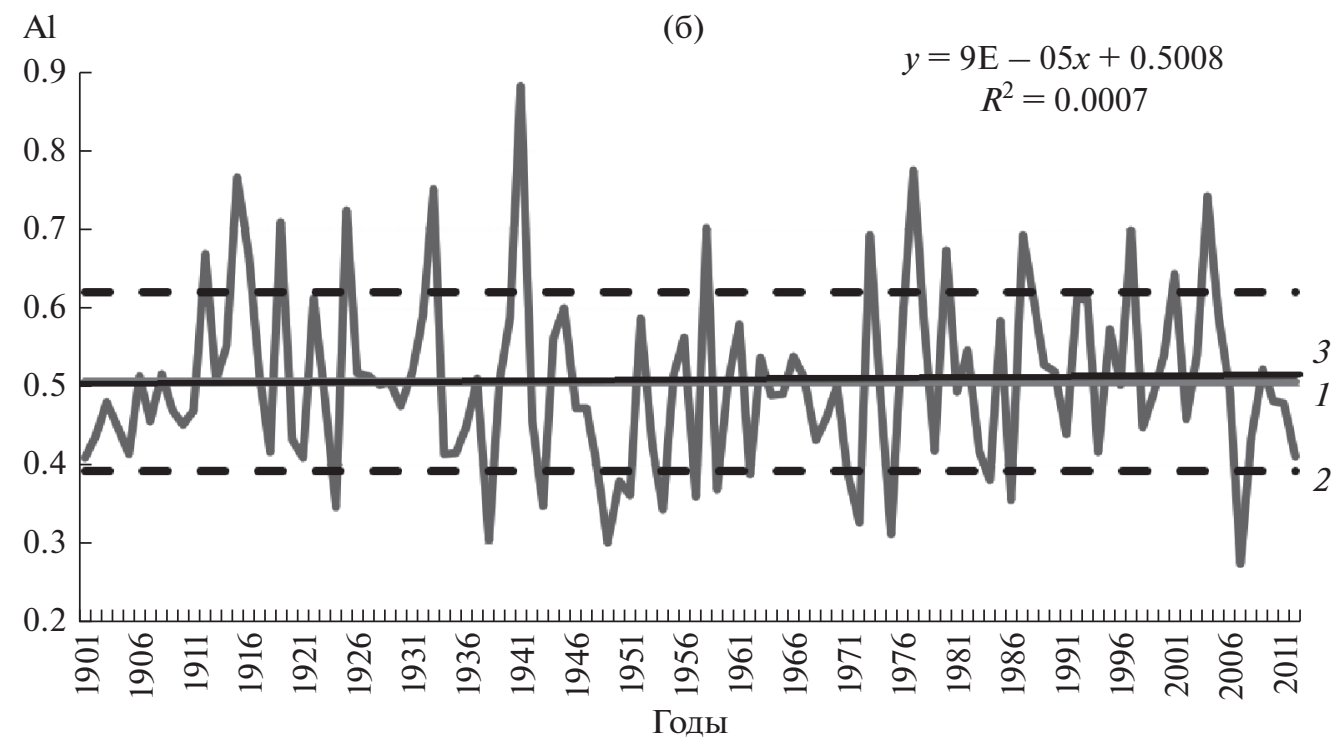

(a)

$$
\begin{gathered}
y=0.0004 x+0.2788 \\
R^{2}=0.0479
\end{gathered}
$$


Таблища 1. Средний по области индекс аридности (1) и его стандартное отклонение (2) по климатическим периодам

\begin{tabular}{l|c|c|c|c|c|c|c|c|c|c}
\hline \multirow{2}{*}{\multicolumn{1}{c|}{ Субъект РФ }} & \multicolumn{2}{|c|}{$1901-1930$} & \multicolumn{2}{|c|}{$1931-1960$} & \multicolumn{2}{|c|}{$1961-1990$} & \multicolumn{2}{|c|}{$1991-2012$} & \multicolumn{2}{c}{$1901-2012$} \\
\cline { 2 - 10 } & 1 & 2 & 1 & 2 & 1 & 2 & 1 & 2 & 1 & 2 \\
\hline Оренбургская область & 0.52 & 0.11 & 0.51 & 0.14 & 0.54 & 0.13 & 0.53 & 0.12 & 0.53 & 0.13 \\
Саратовская область & 0.50 & 0.12 & 0.48 & 0.12 & 0.54 & 0.13 & 0.52 & 0.10 & 0.51 & 0.12 \\
Волгоградская область & 0.43 & 0.11 & 0.42 & 0.12 & 0.43 & 0.10 & 0.42 & 0.08 & 0.42 & 0.10 \\
Республика Калмыкия & 0.28 & 0.05 & 0.31 & 0.07 & 0.30 & 0.06 & 0.33 & 0.05 & 0.30 & 0.06 \\
Астраханская область & 0.22 & 0.05 & 0.24 & 0.06 & 0.25 & 0.07 & 0.26 & 0.04 & 0.24 & 0.05 \\
Ростовская область & 0.51 & 0.10 & 0.49 & 0.13 & 0.51 & 0.11 & 0.52 & 0.11 & 0.51 & 0.11 \\
Ставропольский край & 0.47 & 0.08 & 0.50 & 0.11 & 0.48 & 0.09 & 0.49 & 0.07 & 0.48 & 0.09 \\
\hline
\end{tabular}

Таблица 2. Вероятность по критерию Стьюдента разности средних индексов аридности в субъектах между климатическими периодами

\begin{tabular}{l|c|c|c}
\hline \multicolumn{1}{c|}{ Субъект РФ } & $1901-1930$ & $1931-1960$ & $1961-1990$ \\
\cline { 2 - 4 } & $1931-1960$ & $1961-1990$ & $1991-2012$ \\
\hline Оренбургская область & 0.3 & 0.6 & 0.3 \\
Саратовская область & 0.5 & $\mathbf{0 . 9}$ & 0.5 \\
Волгоградская область & 0.3 & 0.3 & 0.3 \\
Республика Калмыкия & $\mathbf{0 . 9}$ & 0.4 & $\mathbf{0 . 9}$ \\
Астраханская область & 0.7 & 0.3 & 0.6 \\
Ростовская область & 0.6 & 0.5 & 0.4 \\
Ставропольский край & 0.7 & 0.6 & \\
\hline
\end{tabular}

Примечание: Значимая вероятность (0.9) выделена черным шрифтом.

ственно ослабление аридизации характерно для периода 1961-1990 гг., а усиление - в период 1991-2012 гг. Чередование знаков значимых трендов индекса аридности не способствует формированию длительных и устойчивых его тенденций за период 1901-2012 гг.

Следующие результаты раскрывают внутривековые масштабы колебаний аридизации, выявленные методом группирования засушливых и влажных лет [8, 9]. Усиление аридизации происходило в большинстве случаев в отдельные за- сушливые годы, и реже в периоды группировок засушливых несколько лет подряд (2-12 лет).

Как видно из рис. За, самые продолжительные периоды усиления аридизации отмечались в Оренбургской (12 лет), Саратовской и Волгоградской областях (11 лет). Менее продолжительные группировки длительностью 4-6 лет характерны для Республики Калмыкия, Волгоградской, Астраханской, Ростовской областей и Ставропольского края. Всего на исследуемой территории за период 1901-2012 гг. выявлено 6 группировок усиления аридизации (см. рис. 3a).

Таблица 3. Коэффициенты линейного тренда индекса аридности по климатическим периодам

\begin{tabular}{l|c|c|c|c}
\hline \multicolumn{1}{c|}{ Субъект РФ } & $1901-1930$ & $1931-1960$ & $1961-1990$ & $1991-2012$ \\
\hline Оренбургская область & $\mathbf{- 0 . 0 0 1 0}$ & $\mathbf{0 . 0 0 4 6}$ & 0.0001 & $\mathbf{- 0 . 0 0 4 4}$ \\
Саратовская область & $\mathbf{0 . 0 0 3 0}$ & $\mathbf{0 . 0 0 1 8}$ & $\mathbf{0 . 0 0 3 4}$ & $\mathbf{- 0 . 0 0 1 9}$ \\
Волгоградская область & $\mathbf{0 . 0 0 4 9}$ & -0.0003 & $\mathbf{0 . 0 0 1 8}$ & $\mathbf{- 0 . 0 0 2 0}$ \\
Республика Калмыкия & $\mathbf{0 . 0 0 1 3}$ & $-\mathbf{0 . 0 0 1 4}$ & 0.0004 & $\mathbf{- 0 . 0 0 2 9}$ \\
Астраханская область & 0.0007 & 0.0001 & $\mathbf{0 . 0 0 1 5}$ & $\mathbf{- 0 . 0 0 2 6}$ \\
Ростовская область & $\mathbf{0 . 0 0 2 3}$ & $\mathbf{- 0 . 0 0 2 9}$ & $\mathbf{0 . 0 0 2 0}$ & $\mathbf{- 0 . 0 0 4 4}$ \\
Ставропольский край & 0.0000 & $\mathbf{- 0 . 0 0 2 0}$ & -0.0001 & $\mathbf{- 0 . 0 0 2 5}$ \\
\hline
\end{tabular}

Примечание: Значимая вероятность (0.95) выделена черным шрифтом. 
Число случаев

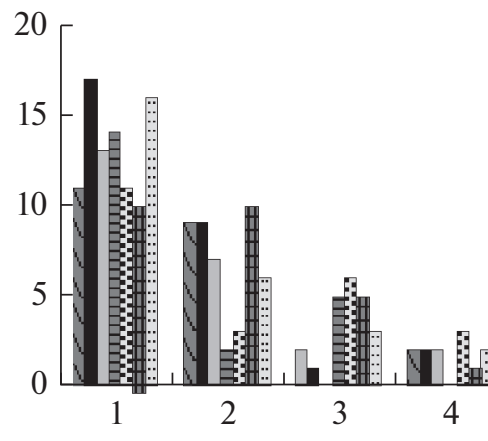

Число случаев

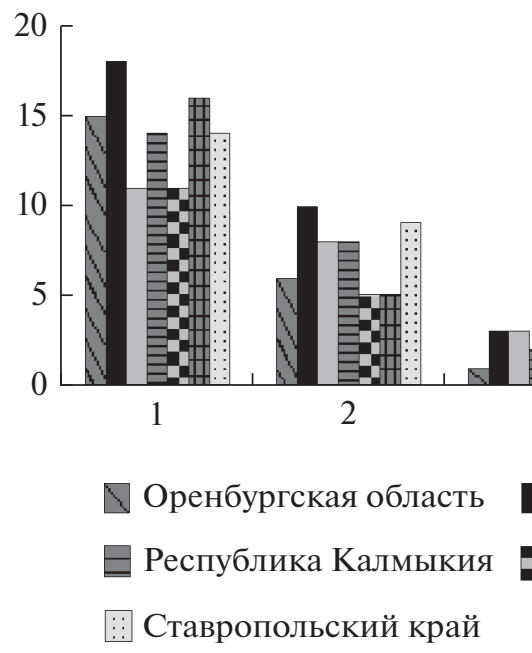

(a) 

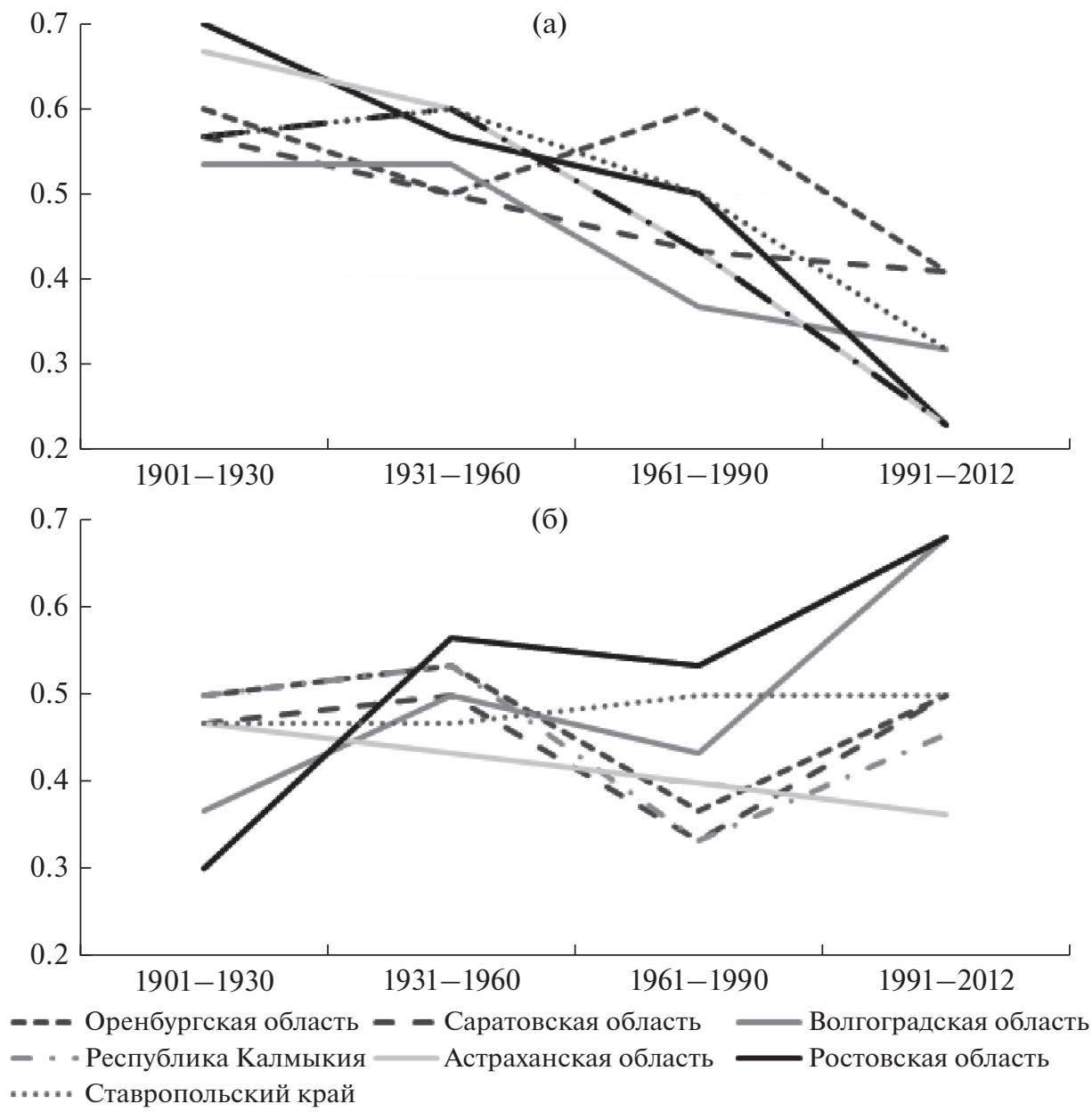

Рис. 4. Частота засух, осредненных по тридцатилетиям, по субъектам РФ, в год: (а) - весенних, (б) - летних.

циркуляции и мультидекадного квазипериодического изменения температуры поверхности Северной Атлантики [15]. Таким образом, компенсация долгопериодных колебаний индекса аридности объясняется, в частности, влиянием температуры поверхности Северной Атлантики на весенние и летние осадки. В теплый период Северной Атлантики в среднем на исследуемой территории наблюдались весенние осадки выше нормы, а летние осадки - ниже нормы. В холодный период Северной Атлантики, наоборот, в среднем весенние осадки ниже нормы, а летние осадки выше нормы.

Рассмотрим результаты анализа частоты и интенсивности весенних и летних засух, осредненных по тридцатилетиям, в каждом субъекте за период 1901-2012 гг. (рис. 4). Если в первой трети века наблюдалось 5-7 засух/10 лет, то в период 1991-2012 гг. число засух сократилось до 2-4 засух/10 лет.

Интенсивность весенних засух медленно уменьшалась с начала века к десятилетию 19611970 гг. Затем она вновь возросла в 1981-1990 гг. в некоторых областях, особенно в Оренбургской,
Саратовской и Астраханской областях. Интенсивность летних засух снижалась в 1911-1920, 1941-1950 и 1981-2000 гг. Она возрастала в 1931$1940,1951-1960$ и 1971-1980 гг.

Повышенная частота летних засух (4-5.5 за десятилетие) отмечалась в период 1931-1960 гг. В следующий период в большинстве субъектов произошло снижение частоты. В период 19912012 гг. разброс частоты по субъектам был максимальным. Частота возросла в большинстве субъектов, особенно в Ростовской и Волгоградской областях. Напротив, в Астраханской области продолжилось снижение частоты, начавшееся еще в первом тридцатилетии.

Сравнение периодов усиления засух с декадными изменениями частоты и интенсивности засух показывает, что на усиление аридизации в большей степени влияет рост частоты и интенсивности летних засух, чем весенних. Весенние засухи не распространялись на всей территории, например, в период 1984-1996 гг. В это время они сместились преимущественно в Оренбургскую, Саратовскую и Волгоградскую области. А после 
Таблица 4. Число весенне-летних, весенних и летних засух (SPI) < 0 на засушливых землях за период 19012012 гг.

\begin{tabular}{l|c|c|c}
\hline \multirow{2}{*}{ Субъект РФ } & \multicolumn{3}{|c}{ Засуха } \\
\cline { 2 - 4 } & $\begin{array}{c}\text { весенняя } \\
\text { и летняя }\end{array}$ & весенняя & летняя \\
\hline Оренбургская область & 30 & 27 & 23 \\
Саратовская область & 28 & 25 & 19 \\
Волгоградская область & 28 & 19 & 24 \\
Республика Калмыкия & 26 & 31 & 23 \\
Астраханская область & 24 & 30 & 22 \\
Ростовская область & 30 & 20 & 30 \\
Ставропольский край & 23 & 30 & 25 \\
\hline
\end{tabular}

1997 г. весенние засухи были уже редки на всей территории. Группировки же летних засух сохранялись на всей территории в 1991-2002 и 20052012 гг. Таким образом, влияние весенних засух после 1997 г. на аридизацию снизилось, а летних сохранилось.

Весенние засухи доминируют по сравнению с летними в Оренбургской, Саратовской, Астраханской, в Республике Калмыкия и Ставропольском крае. Число летних засух больше, чем весенних в Волгоградской и Ростовской областях (табл. 4).

Частота и интенсивность весенних и летних засух в регионе меняется по-разному в условиях продолжающегося глобального потепления. Если частота весенних засух имеет тенденцию к снижению во всех субъектах, то частота летних засух превысила частоту в период 1931-1960 гг. только в Ростовской и Волгоградской областях. Частота в остальных субъектах или не изменилась или была ниже. Интенсивность весенних засух возросла в период 2001-2010 гг. только в Оренбургской, Саратовской, Ростовской областях и Республике Калмыкия, а интенсивность летних засух упала во всех субъектах.

Очевидно, что изменения среднего за тридцатилетия индекса аридности во всех субъектах косвенно говорят об устойчивости аридных зон на ЕЧР. Но в сухие и влажные периоды (не более 10 лет) положение границ аридных зон может временно измениться (см. рис. 1).

Как показано на рис. 1, в период 1930-1939 гг. (изолинии AI, обозначенные пунктирными линиями) на исследуемой территории было суше, чем в среднем за 1901-2012 гг. (полужирные сплошные линии). Изолинии AI в этот период находились севернее положения среднемноголетней, особенно АI $=0.75$. Исключение представляет изолиния АI $=0.35$, смещение которой от положения изолинии со среднемноголетним значением было незначительным.

В период 1987-1996 гг. было напротив более влажно и изолинии АI (тонкие сплошные линии) сместились к югу, особенно АI = 0.35 (см. рис. 1). В это время на территории Республики Калмыкия проявилось значимое ослабление аридизации с последующим “остепнением”. Следует отметить наибольшее отклонение изолиний от среднемноголетнего значения на субгумидной территории в сухое десятилетие, чем во влажное.

Скорость деградации земель в областях определена по значимым коэффициентам линейного тренда для двух месяцев альбедо (май и август). В мае наибольшая скорость роста альбедо отмечалась в Астраханской области и Республике Калмыкия. Меньшей скоростью отличались Саратовская и Волгоградская области, а наименьшей Оренбургская область и Ставропольский край. Скорость роста альбедо поверхности и, следовательно, деградации земель возросла в августе во всех областях (рис. 5).

Известно, что опустынивание означает взаимодействие аридизации, включающей засухи, и деградации земель. Так как аридизация засушливых земель ЕЧР не прогрессирует в течение более, чем 100 лет, деградация земель становится здесь доминирующим фактором опустынивания. Но при этом антропогенная аридизация и, следовательно, опустынивание остаются зависимыми к выявленным климатическим колебаниям индекса аридности.

\section{ЗАКЛЮЧЕНИЕ}

Выявлена основная причина устойчивости аридных зон на ЕЧР за период 1901-2012 гг. в условиях меняющегося климата: взаимная компенсация внутривековых колебаний индекса аридности.

Процесс аридизации на засушливых землях ЕЧР в период 1901-2012 гг. можно представить в виде чередующихся засушливых и влажных группировок лет различной длительности, которые формируют внутривековые колебания аридизации. Аридизация усиливалась в периоды группировок засушливых лет продолжительностью от 2 до 12 лет, а также в течение расширенных группировок, состоящих из нескольких небольших группировок, включающих дополнительно еще однолетние засухи. Такие расширенные группировки наблюдались в периоды 1929-1940 и 19651984 гг., а самые длительные группировки охватывали все рассматриваемые субъекты РФ. Чере- 


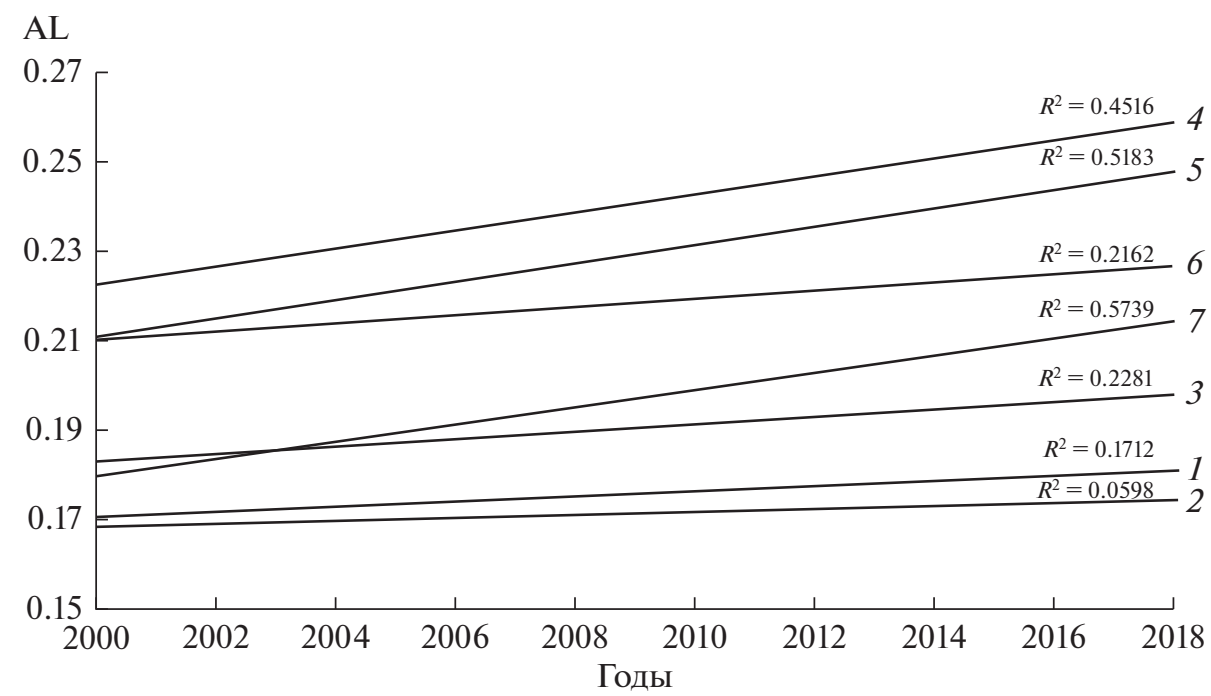

Рис. 5. Линейный тренд альбедо AL в августе по субъектам РФ: 1 - Оренбургская область, 2 - Саратовская область, 3 - Волгоградская область, 4 - Астраханская область, 5 - Республика Калмыкия, 6 - Ставропольский край, 7 - Ростовская область.

дование группировок засушливых и более коротких влажных лет - характерная особенность внутривековой аридизации климата данной территории, регулируемая междугодовой изменчивостью сезонных осадков. Это чередование не способствует формированию длительных устойчивых тенденций индекса аридности.

Незначимость линейных трендов индекса аридности за период 1901-2012 гг. не свидетельствует в пользу гипотезы систематического усиления аридизации в условиях продолжающегося глобального потепления, хотя некоторое ослабление аридизации в последние два десятилетия наблюдалось на территории Астраханской области и Республики Калмыкия. Относительную устойчивость границ аридных зон за период исследования можно объяснить взаимной компенсацией внутривековых колебаний аридизации и практически отсутствующими значимыми линейными трендами индекса аридности в период 1901-2012 гг. Но при сравнении сухих и влажных периодов (не более 10 лет) положение границ аридных зон может временно измениться.

На усиление аридизации в большей степени влияет рост частоты и интенсивности летних засух, чем весенних. Частота весенних засух имеет тенденцию к снижению, а их интенсивность была максимальной в десятилетие 1981-1990 гг. Частота и интенсивность летних засух повышалась в периоды группировок лет усиления аридизации.

Частота и интенсивность весенних и летних засух в регионе меняется по-разному в условиях продолжающегося глобального потепления. Если частота весенних засух имеет тенденцию к снижению во всех субъектах, то частота летних засух превысила максимальную частоту в период 19311960 гг. только в Ростовской и Волгоградской областях. Частота в остальных субъектах или не изменилась или была ниже. Интенсивность весенних засух возросла в период 2001-2012 гг. только в Оренбургской, Саратовской, Ростовской областях и Республике Калмыкия, а интенсивность летних засух упала во всех субъектах.

Принимая во внимание оценки трендов альбедо, высокая скорость деградации земель характерна для Астраханской области и Республики Калмыкия, а низкая - для Оренбургской области и Ставропольского края.

Опустынивание означает взаимодействие аридизации, включающей засухи, и деградации земель. Так как аридизация засушливых земель ЕЧР не прогрессирует в течение более, чем 100 лет, деградация земель становится здесь доминирующим фактором опустынивания.

\section{ФИНАНСИРОВАНИЕ}

Исследование трендов увлажнения проведено в рамках научной темы № 0148-2019-0009 (AAAA-A19119022190173-2). Анализ частоты засух выполнен при финансовой поддержке Российского научного фонда (проект 19-17-00242). 


\section{FUNDING}

The study of humidification trends was conducted within the framework of the scientific theme no. 0148-20190009 (AAAA-A19-119022190173-2). Drought frequency analysis was carried out with the financial support of the Russian Science Foundation, project no. 19-17-00242.

\section{СПИСОК ЛИТЕРАТУРЫ}

1. Золотокрылин А.Н., Виноградова В.В. Соотношение между климатическим и антропогенным факторами восстановления растительного покрова юговостока Европейской России // Аридные экосистемы. 2007. Т. 13. № 33-34. С. 7-16.

2. Золотокрылин А.Н., Черенкова Е.А. Площадь засушливых земель равнин России // Аридные экосистемы. 2009. Т. 15. № 1 (37). С. 5-12.

3. Золотокрылин А.Н., Черенкова Е.А. Динамика зон увлажнения суббореальных ландшафтов России в XX-XXI вв. // Изв. РАН. Сер. геогр. 2011. № 4. C. 33-41.

4. Золотокрылин А.Н., Черенкова Е.А. Тенденции увлажнения зернового пояса России в начале XXI века // Проблемы экологического мониторинга и моделирования экосистем. 2013. Т. 25. С. 251-264.

5. Золотокрылин А.Н., Титкова Т.Б., Черенкова Е.А. Увлажнение засушливых земель европейской территории России: настоящее и будущее // Аридные экосистемы. 2014. Т. 4. № 2. С. 49-54.

6. Кулик К.Н., Петров В.И., Рулев А.С., Кошелева О.Ю., Шинкаренко C.C. К 30-летию "генеральной схемы по борьбе с опустыниванием Черных земель и Кизлярских пастбищ” // Аридные экосистемы. 2018. T. 8. № 1. С. 1-6.

7. Неронов В.В., Чабовский Л.В. Черные земли: полупустыня вновь становится степью // Природа. 2003. № 2. С. 72-79.

8. Раунер Ю.Л. Группировка засушливых лет в зерновой зоне СССР // Изв. АН СССР. Сер. геогр. № 5. 1982. C. $38-51$.

9. Раунер Ю.Л. Климат и урожайность зерновых культур. М.: Наука, 1981. 162 с.
10. Сапанов М.К. Экологические последствия потепления климата в Северном Прикаспии // Аридные экосистемы. 2018. Т. 8. № 1. С. 13-21.

11. Черенкова Е.А., Шумова Н.А. Испаряемость в количественных показателях климата // Аридные экосистемы. 2007. Т. 13. № 33-34. С. 55-67.

12. Черенкова Е.А., Золотокрылин А.Н. Реакция границ зон увлажнения равнин России на изменения климата // Метеорология и гидрология. 2010. Т. 35. № 12. C. 799-805.

13. Черенкова Е.А., Золотокрылин А.Н. Модельные оценки динамики увлажнения равнин России к середине XXI в. // Метеорология и гидрология. 2012. T. 37. № 11-12. С. 704-710.

14. Черенкова Е.А., Золотокрылин А.Н. О сравнимости некоторых количественных показателей засухи // Фундаментальная и прикладная климатология. 2016. T. 2. С. 79-94.

15. Черенкова E.A. Сезонные осадки на территории Восточно-Европейской равнины в периоды теплых и холодных аномалий температуры поверхности Северной Атлантики // Изв. РАН. Сер. геогр. 2017. № 5. C. 72-81.

16. Allen R.G., Pereira L.S., Raes D., Smith M. Crop evapotranspiration-Guidelines for computing crop water requirements-FAO Irrigation and drainage paper 56. Rome: FAO, 1998. 300 p.

17. Harris I., Jones P.D., Osborn T.J., Lister D.H. Updated high-resolution grids of monthly climatic observations the CRU TS3.10 Dataset // Int. journal of climatology. 2014. V. 34. № 3. P. 623-642.

18. Penman H.L. Natural evaporation from open water, bare soil and grass // Proc. Roy. Soc. A. 1948. V. 193. № 1032. P. 120-145.

19. Penman H.L. Estimating evaporation // Eos, Trans. Am. Geophys. Union. 1956. V. 37. № 1. P. 43-50.

20. Thornthwaite C.W. An approach toward a rational classification of climate // Geogr. Rev. 1948. V. 38. № 1. P. 55-94.

21. Report of the United Nations Conference on Environment and Development, Rio de Janeiro, 3-14 June 1992. NY: UN, 1993. V. 1. 486 p.

\title{
Aridization of Drylands in the European Part of Russia: Secular Trends and Links to Droughts
}

\author{
A. N. Zolotokrylin ${ }^{1}$, E. A. Cherenkova ${ }^{1, ~ \#, ~ a n d ~ T . ~ B . ~ T i t k o v a ~}{ }^{1}$ \\ ${ }^{1}$ Institute of Geography RAS, Moscow, Russia \\ ${ }^{\#}$ e-mail: cherenkova@igras.ru
}

\begin{abstract}
Secular trends in humidification in seven southern regions of the European part of Russia were investigated. Land degradation trend was assessed based on satellite albedo data at the beginning of the current century. Mutual compensation of intra-centuries fluctuations of the aridity index drives to the stability of arid zones in drylands. The insignificance of linear trend of the aridity index for the period 1901-2012 does not confirm the hypothesis of systematic strengthening of the aridization under ongoing global warming. The analysis of dry and wet years' groups of the different duration revealed the decrease of the frequency of spring droughts, and their intensity achieved the maximum in 1981-1990. Frequency and intensity of summer droughts in-
\end{abstract}


creased during the periods corresponding to the groups of growing aridization years. In the progress absence in aridization of drylands of the European part of Russia for more than 100 years, increased land degradation becomes the dominant factor of desertification.

Keywords: aridization, trends, aridity index, standardized precipitation index, drought, drylands, European part of Russia

\section{REFERENCES}

1. Zolotokrylin A.N., Vinogradova V.V. Relation between climatic and anthropogenic factors of re-vegetation in the South-East of European Russia. Arid. Ekosist., 2007, vol. 13, no. 33-34, pp. 7-16. (In Russ.).

2. Zolotokrylin A.N., Cherenkova E.A. The area of the dry plain lands of Russia. Arid. Ekosist., 2009, vol. 15, no. 1(37), pp. 5-12. (In Russ.).

3. Zolotokrylin A.N., Cherenkova E.A. Dynamics aridity zones of subboreal landscapes of Russia in XX-XXI centuries. Izv. Akad. Nauk, Ser. Geogr., 2011, no. 4, pp. 33-41. (In Russ.).

4. Zolotokrylin A.N., Cherenkova E.A. Moistening tendencies in grain-growth zone of Russia in beginning of 21st Century. Probl. Ekol. Monit. Model. Ekosist., 2013, vol. 25, pp. 251-264. (In Russ.).

5. Zolotokrylin A.N., Titkova T.B., Cherenkova E.A. Humidification of drylands in European Russia: The present and future. Arid. Ecosyst., 2014, vol. 4, no. 2, pp. 49-54. doi 10.1134/S2079096114020127

6. Kulik K.N., Petrov V.I, Rulev A.S., Kosheleva O.Yu., Shinkarenko S.S. On the 30th anniversary of the "General Plan to Combat Desertification of Black Lands and Kizlyar Pastures". Arid. Ecosyst., 2018, vol. 8, no. 1, pp. 1-6. doi 10.1134/S2079096118010067

7. Neronov V.V., Chabovskii L.V. Black lands: semi-desert becomes steppe again. Priroda, 2003, no. 2, pp. 7279. (In Russ.).

8. Rauner Yu.L. Grouping of dry years in the grain zone of the USSR. Izv. Akad. Nauk, Ser. Geogr., 1982, no. 5, pp. 38-51. (In Russ.).

9. Rauner Yu.L. Klimat $i$ urozhainost' zernovykh kul'tur [Climate and Yield of Grain Crops]. Moscow: Nauka Publ., 1981. 162 p.

10. Sapanov M.K. Environmental implications of climate warming for the Northern Caspian region. Arid. Ecosyst., 2018, vol. 8, no. 1, pp. 13-21. doi $10.1134 /$ S2079096118010092
11. Cherenkova E.A., Shumova N.A. Potential evapotranspiration in quantity indicators of climate. Arid. Ekosist., 2007, vol. 13, no. 33-34, pp. 55-67. (In Russ.).

12. Cherenkova E.A., Zolotokrylin A.N. Reaction of boundaries of moistening zones of the Russian plains to the climate changes. Russ. Meteorol. Hydrol., 2010, vol. 35 , no. 12 , pp. $799-805$. doi 10.3103/S1068373910120022

13. Cherenkova E.A., Zolotokrylin A.N. Model estimates of moistening conditions on the Russian plains by the middle of the 21st century. Russ. Meteorol. Hydrol., 2012, vol. 37, no. $11-12$, pp. 704-710. doi 10.3103/S1068373912110039

14. Cherenkova E.A., Zolotokrylin A.N. On the comparability of some quantitative indicators of drought. Fundam. Prikl. Klimatol., 2016, vol. 2, pp. 79-94. (In Russ.).

15. Cherenkova E.A. Seasonal precipitation in the East European Plain during the periods of warm and cool anomalies of the North Atlantic surface temperature. Izv. Ross. Akad. Nauk. Ser. Geogr., 2017, no. 5, pp. 7281. (In Russ.).

16. Allen R.G., Pereira L.S., Raes D., Smith M. Crop Evapotranspiration. Guidelines for Computing Crop Water Requirements. FAO Irrigation and Drainage Paper, no. 56. Rome: FAO, 1998. 300 p.

17. Harris I., Jones P.D., Osborn T.J., Lister D.H. Updated high-resolution grids of monthly climatic observations - the CRU TS3.10 Dataset. Int. J. Climatol., 2014 vol. 34, no. 3, pp. 623-642.

18. Penman H.L. Natural evaporation from open water, bare soil and grass. Proc. Roy. Soc. A, 1948, vol. 193, no. 1032, pp. 120-145.

19. Penman H.L. Estimating evaporation. Eos, Trans. Am. Geophys. Union, 1956, vol. 37, no. 1, pp. 43-50.

20. Thornthwaite C.W. An approach toward a rational classification of climate. Geogr. Rev., 1948, vol. 38, no. 1, pp. 55-94.

21. Report of the United Nations Conference on Environment and Development, Rio de Janeiro, 3-14 June 1992. NY: UN, 1993, vol. 1. 486 p. 